\title{
Exploring the hinterlands: avant-garde temporality, socialist realism, and
}

\section{Pogodin's Aristocrats}

\section{Amy Skinner}

\begin{abstract}
$\underline{\text { Abstract }}$
Soviet socialist realism is frequently constructed as the death knell of the Russian avant-garde. The combination of vague instructions (mainly concerning the required effect of the work, rather than its formal construction) with severe consequences for non-compliance restricted the appetite for experimentation amongst Soviet writers of the socialist realist era. This article considers the relationship between avant-garde technique and the socialist realist project through a case study of one of the earliest socialist realist plays, Nikolai Pogodin's Aristocrats (1934-5). Through analysis of the temporal aesthetic underwriting Pogodin's play, the article explores how avant-garde approaches to temporality continue to influence post-avant-garde play-texts, suggesting a model for the theatrical transitions that occur at the avant-garde hinterlands. Finally, it turns to the production of Pogodin's play under Nikolai Okhlopkov at the Realistic Theatre and his use of the vortex form as a scenographic idiom. The article concludes by arguing that these hinterland texts, where avant-garde technique serves socialist realist intentions, form a vital moment in understanding how a legacy for Russian avant-garde practice can be defined.
\end{abstract}

\section{$\underline{\text { Key words }}$}

Avant-garde; socialist realism; Pogodin; Okhlopkov; temporal aesthetics; vortex 


\section{Exploring the Hinterlands:}

\section{$\underline{\text { Avant-Garde Temporality, Socialist Realism, and Pogodin's Aristocrats }}$}

The slogan of 'socialist realism' has been regarded by independent historiography both within the Soviet Union and elsewhere as merely a bugaboo used by the censorship to persecute and destroy "genuine art" and its creators. Viewed from this perspective, the entire Stalin period is one long martyrology or history of persecutions, which it indeed undoubtedly was.

(Groys 2011, 5)

This article is concerned with the avant-garde hinterlands; that is, the moments when avantgarde practice shifts and develops into new, post-avant-garde, theatrical languages. The hinterlands are the outer edges of a territory, the point at which one space transitions into another. With cultural movements, this notion of linear transition is problematic: the historical avant-garde is a collection of aesthetics and affiliations that overlap and interact, forming a diverse cultural landscape. ${ }^{1}$ However, in Soviet Russia, as Boris Groys notes, the introduction of socialist realism as the official style of art-making initiated an enforced shift away from avant-garde practice, a false borderline or boundary that artists were required to cross. Associated with persecution and 'martyrology', the socialist realist moment imposed a new aesthetic vocabulary on Russian theatre practice that, in Western scholarship, is frequently seen as distasteful and destructive; to borrow Groys' words, the antithesis to 'genuine art'.

For the Soviet state, socialist realism was used to halt the perceived dangers of 'formalism', reframing the avant-garde experiments of practitioners like Vsevolod Meierkhold and Alexander

\footnotetext{
${ }^{1}$ It should be noted that the avant-garde discussed here is that which Schechner $(1996,2002)$ would perhaps term 'historical', that is, I am considering a specific, historical manifestation of avant-garde practice (Russia, early twentieth century), rather than a broader, formal definition.
} 
Tairov as counter to Communist ideologies. The introduction of this new aesthetic, however, was fraught with complications, most notably in the vagueness of instructions issued to artists and writers. In addition, framed by nearly three decades of innovation in Russian theatre making, playwrights and directors attempting to engage with socialist realist principles were located within a culture of embedded avant-garde experimentation. ${ }^{2}$ As much as socialist realism was created as a rebuttal to the avant-garde, the reality of the theatrical landscape ensured that the early socialist realist texts are in fact an integral part of avant-garde history, demonstrating how these hinterland moments function, and suggesting that elements of avantgarde practice became essential aesthetic foundations for socialist realist theatre makers. Indeed, more than a distasteful 'bugaboo' to be ignored or minimalized in the history of the avant-garde, the early socialist realist plays are a significant part of the Soviet avant-garde narrative.

Beginning with an outline of the challenges that socialist realism presented to Soviet playwrights, this article considers the relationship between avant-garde technique and the socialist realist project through a case study of one of the earliest socialist realist plays, Nikolai Pogodin's Aristocrats [Aristokraty] (1934-5). Through analysis of Pogodin's temporal aesthetic (that is, the way in which the artwork incorporates contemporary temporal philosophy), the article explores how avant-garde approaches to temporality continue to influence post-avant-garde play-texts, suggesting a model for the theatrical transitions that occur at the avant-garde hinterlands. Finally, it turns to the production of Pogodin's play under Nikolai Okhlopkov at the Realistic Theatre and his use of the vortex form as a scenographic

\footnotetext{
${ }^{2}$ Russian art collector George Costakis dates the advent of the avant-garde in Russian visual art in 1910 (see Rudenstine 1981, 11). In terms of theatre making, the early 1900s saw moves away from naturalism (arguably the first avant-garde) towards European symbolist influences (seen, for example, in Meierkhold's experiments at the Moscow Art Theatre Studio or in the discussions at Vyacheslav Ivanov's Tower group in St. Petersburg).
} 
idiom, concluding that these hinterland productions, where avant-garde technique serves socialist realist intentions, form a vital moment in understanding how a legacy for Russian avant-garde practice can be defined.

\section{The socialist realist challenge}

From its announcement at the 1934 Soviet Writers' Congress, socialist realism presented Russia's playwrights with the very specific challenge of interpreting in practice the policy of an overtly pro-Soviet theatre. In light of Stalin's framing of writers as the 'engineers of the soul' (Solovyova 1999, 328), the intended purpose of socialist realist writing was far clearer than its formal requirements. Marc Slonim notes the combination of formal vagueness and required conformity in the socialist realist 'formula':

Theoretically, the formula of socialist realism was contradictory and vague since it confused such different concepts as aesthetic method, artistic intention, requirements of a school, and political demands. But in practice it became an inviolable table of the Communist credo, and it required political conformity and traditional form (Slonim 1961, 307).

This 'traditional form', as Slonim explains, translated to an adherence to representation, interpreted as broadly realist:

The official introduction of the formula signified the banishment of experimentation and of artistic avant-garde, as well as obedience to strictures of representational art, ranging from sheer naturalism and factography to psychological realism in an oldfashioned manner (Slonim 1961, 307).

Speaking at the Writers' Congress, Andrei Zhdanov, Secretary of the CPSU [Communist Party of the Soviet Union] Central Committee, also highlighted the necessity for realism, which he blurred with romanticism in service of Soviet ideology:

To be an engineer of human souls means standing with both feet firmly planted on the basis of real life. And this in turn denotes a rupture with romanticism of the old type, which depicted a non-existent life and non-existent heroes, leading the reader away from the antagonisms and oppression of real life into a world of the impossible, into a 
world of utopian dreams. Our literature, which stands with both feet firmly planted on a materialist basis, cannot be hostile to romanticism, but must be a romanticism of a new type, revolutionary romanticism (Zhdanov 1977, 21).

The blend of romanticism and realism creates a tension that underwrites the form, in which the believable and the heroic must be reconciled. For Anatoly Smeliansky this tension leads to a form of 'naturalism without the nature', whose main features were 'rationalism, didacticism, clarity and simplicity' (Smeliansky 1999, 2), indicating that the emphasis was placed more on the communication of ideas than the definition of form. Similarly, Inna Solovyova describes a theatre of positive values, encouraging belief in the party and party policy, the intricacies of whose expression in terms of form and style were communicated to writers through 'hints' rather than a clear diktat (Solyoyova 1999, 330). A. I. Stetsky, Manager of the Culture and Leninist Propaganda Section of the Central Committee of the CPSU, tackled the issue of a lack of clear aesthetic guidance in his speech to the Writers' Congress, indicating both the nebulous nature of socialist realism and the high stakes that the introduction of the policy implied for Soviet writers:

Socialist realism is not some set of tools that are handed out to the writer for him to make a work of art with. Some writers demand that they be given a theory of socialist realism complete in all its details. You represent the best part of the intelligentsia. 'To whom much is given, from him much shall be exacted.' And when we are told that we must show socialist realism, there is only one answer which we can give here, at this congress of writers: socialist realism can best be shown in those works of art which Soviet writers produce (Stetsky 1977, 265).

Stetsky's speech suggests how the overt agenda of socialist realism has led to a post-facto construction of these plays as a moment of stagnation in Russian literary and theatrical history. Placing the emphasis on a writer's Soviet pedigree demonstrates the collapse of socialist realist writing with Soviet values, suggesting that the failure to produce an acceptable socialist realist text might indicate that a writer is not Soviet enough. Framed by the growing momentum of 
Stalin's purges, the consequences of non-compliance with socialist realist policy were severe, and the lack of guidance naturally restricted many writers' appetites for experimentation. The resulting plays' often formulaic plots and overly sincere character conversions can seem facile when read against the broad scope of artistic experimentation that characterised early Soviet playwriting, seen, for example in Vladimir Mayakovsky's futurist works, including his reworked mystery play Mystery Bouffe [Misteriya-buff] (1918-1921) or his proto-science fiction work The Bedbug [Klop] (1928-9).

However, as Groys notes, the perceived avant-garde/socialist realist binary conceals a more fluid relationship between these two cultural moments. Outlining a 'conceptual pattern by which the internal evolution of Stalinist culture may be understood' (Groys 2011, 13), he claims that:

Socialist realism was not created by the masses but was formulated in their name by well-educated and experienced elites who had assimilated the experience of the avantgarde and been brought to socialist realism by the internal logic of the avant-garde method itself, which had nothing to do with the actual tastes and demands of the masses (Groys 2011, 9).

Groys articulates an assimilation of avant-garde experience within socialist realism which underwrites the argument presented in this article: that, despite clear short-comings and moral complexities, early socialist realist drama, such as Pogodin's play Aristocrats, maintains a connection to the art of the avant-garde, particularly through the temporal aesthetic of simultaneity on which it is founded.

\section{The Journey to Belomor: Pogodin and Aristocrats}

In August 1933, Pogodin was invited to join a Writers' Brigade visit to the forced labour camps along the site of the reconstructed canal connecting the Baltic with the White Sea (the 
Byelmorsko-Baltiyskiy Kanal imeni Stalina, or Belomor Canal). The trip, coordinated by Maxim Gorky, is described by Dutch journalist Frank Westerman in his travelogue Engineers of the Soul:

The secret police of the GPU [Gosudarstvennoye Politicheskoye Upravleniye, or State Political Directorate], [the Literaturnaya Gazeta] says, have organised the excursion [...] down to the most minute detail. Their destination: the Gulag. Through Gorky's intercession, the writers will be given the chance to view at close quarters this new correctional system based on the concept of 're-education through physical labour'. To that end, they will visit penal camps along the Belomor Canal, which is now nearing completion. The canal [...] has been dug by hand by forced-labour crews ('canal soldiers') and is now seen as the crowning accomplishment of the First Five-Year Plan (Westerman 2011, 59-60). ${ }^{3}$

Built between 1931 and 1933 by around 126,000 prisoners, the canal had a dual purpose: it functioned as both an important trade route for the Soviet Union and a site for the 're-education' that Westerman describes, undertaken as part of a brief ideological scheme called perekovka, or 'reforging', which targeted individuals who showed resistance to Soviet ideology. The choice of nomenclature, as Julie Drascokzy notes, is telling:

By invoking the smelting of metals, the term perekovka adeptly highlighted the industrial atmosphere of Stalin's First Five-Year Plan and asserted that —along with factories, plants, and waterways - people could be constructed according to a master design (Drascokzy 2012, 30).

This collapse of the restructuring of the landscape with the reforging of the resistant individual's attitude highlights the vividly metaphorical function of Belomor and its potential as raw material for Soviet literature:

'Take, for example, the Belomor Canal,' Gorky has been exhorting his colleagues for the last year. 'That is already a visible change in our geography. Is it not, then, the perfect theme for us Soviet writers?' (Westerman 2011, 60).

\footnotetext{
${ }^{3}$ The GPU, also known as the OGPU, or Joint State Political Directorate, were Russia's secret police from 1923 until 1934.
} 
By the time of the Belomor trip, Pogodin had been writing professionally for thirteen years, and had seen a number of his plays produced. As a playwright, his preference was for topics which resonated well with the socialist realist project, particularly focusing on mass industrialization: his plays Tempo [Temp] (1929), The Poem of the Axe [Poema o topore] (1930) and My Friend [Moi drug] (1931) were all located in factory settings. Echoing his commitment to playwriting that deals with Soviet issues, Pogodin is perhaps best known for his trilogy of plays about Lenin, for which he won the Lenin Prize: Man with a Gun [Chelovek s ruzhyom] (1937), Kremlin Chimes [Kremlyovskie kuranty] (1940), and The Third: Pathetic [Tretya pateticheskaya] (1958). Marc Slonim notes the significance of Pogodin's background as a journalist, commenting that 'all of his plays, particularly the early ones, seemed to be dramatization of factual reports on current events' (Slonim 1961, 311). His response to the trip to Belomor also followed this trend, and after the Writers' Brigade excursion, Pogodin chose to make perekovka the central conceit of his play Aristocrats, a four-act comedy in which bandits, political prisoners and wreckers are reformed by hard labour, education and responsibility, under the watchful and often compassionate eye of Gromov, the camp commandant.

Cynthia Ann Ruder writes that:

Pogodin viewed the Belomor project as a most appropriate topic for a dramatist. In his speech to the First Congress of Writers in 1934, he noted that the Belomor project provided him with three elements that appealed especially to a playwright: the colorful [sic] blend of various social strata in one place, the conflicting goals among all the participants at Belomor, from OGPU men to common criminals, and the victory of the most powerful force (the OGPU and perekovka, CR) over its opposing forces (Ruder 1998, 156).

Aristocrats opens with the arrival of a group of new prisoners at the Headquarters of the Belomor camp. The play follows their progress, focusing particularly on two sets of characters: 
criminals and wreckers. Amongst the criminals are Kostya, an infamous conman known as The Captain, and Sonya, a prostitute and drug addict. Through these focal characters, the audience are introduced to the groups of men and women who provide the manual labour for the canal, and witness how Kostya and Sonya emerge as their respective leaders. Inspired by Gromov's respectful attitude, Kostya and Sonya slowly beginning to use their influence for the greater good of the project, rather than to sabotage the canal's progress. A battle between the sexes spurs both groups into useful labour, and Kostya emerges as a strong leader, given the responsibility of overseeing a workforce tasked with the job of blowing up the cliffs. The play closes with him addressing the gathered prisoners, extolling his personal change as a result of his time at Belomor.

The wreckers are represented through two engineers, Sadovsky and Botkin, educated men with a bourgeois outlook who refuse to use their skills to contribute to the canal project. Rather than being subjected to manual labour, their role is to lead and oversee the technical side of the project, making use of their training and talent. Their conversion to the Soviet point of view is slow and marked by dialogue with each other, Gromov and Kostya, and it is Sadovsky's realisation of the futility of his actions as a wrecker that leads to his final transformation. Pogodin's representation of Gromov is key to the play's message, and the character becomes a reflection of the actions of the CPSU, seen as wise, firm, benevolent and with an overriding concern for the contribution of individuals to the greater good: when Kostya's re-education is hindered by the careless actions of a member of the camp staff to whom he is briefly engaged, for example, it is Gromov's wise leadership that brings him back to the fold. Despite a degree of psychological complexity in the characters, Pogodin's play is not ideologically complex, and ultimately the canal is completed and, perhaps more importantly, the prisoners are reformed. The final scene shows the prisoners celebrating their 'second spring' (Pogodin 1937, 
302), a Soviet re-birth achieved through the work at Belomor, as the first ship - appropriately named The Chekist - sails through the canal. ${ }^{4}$

In terms of form, the play is broadly realist, with an emphasis on character development, and, in places, light physical comedy. The message is overwhelmingly pro-Soviet; however, this straight-forward socialist realist reading of the play is complicated by the moment of its creation: written in 1934, and premiered in 1935, the play falls at the very start of the socialist realist period, and certainly in the avant-garde hinterlands. The wider context in theatrical Moscow was still mixed, with elements of avant-garde experimentation sitting alongside the emerging socialist realist genre. Even Aristocrats itself has a mixed production history: Boris Zakhava and Nikolai Okhlopkov produced the play in 1935, both directors with direct links to significant figures of the early twentieth century avant-garde. Zakhava worked as an actor under Yevgeny Vakhtangov and at the Vakhtangov Theatre he had, in Norris Houghton's words, 'become the leading régisseur for plays which require psychological handling' (Houghton 1938, 153). His work on Aristocrats was a relatively straightforward realisation of the text which, in Nick Worrall's words, had '[focussed] on the psychological experience of one of the criminals and failed to come to grips with the humour of the play' (Worrall 1989, 161). In contrast, Okhlopkov's work at the Realistic Theatre was 'a direct challenge to the realistic style adopted by [...] Zakhava' (Worrall 1989, 161). Despite a realistic approach to the psychology of the characters, Houghton notes that Okhlopkov's production drew its influences from the commedia dell'arte and oriental theatre. Reflecting on his experiences

\footnotetext{
${ }^{44}$ The Chekist is a reference to members of the Cheka, Russia's secret police prior to the OGPU. In Anthony Wixley's translation of Aristocrats, the staff of the camp at Belomor, including Gromov, are referred to as Chekists.
} 
visiting the Moscow theatre scene during the 1930s and working at the Realistic Theatre, André van Gyseghem describes the production's aesthetic:

Aristocrats is in some ways a culmination of Okhlopkov's work [...] It is a modern miracle play, produced in a manner so simplified, and at the same time so highly conventionalized as to place on the imagination of the audience half the onus of its effect. The spectator is given, as it were, a sign-post to the path and the rest of the way he goes himself. It speaks volumes for the theatre's belief in the capacity of its audience [...] (van Gyseghem 1943, 199).

Van Gyseghem's highlights the place of the spectator at the centre of Okhlopkov's approach to theatre making. The activation of the spectator's imagination is achieved in the production through what van Gyseghem calls 'conventionalization', techniques including the use of a fabric to represent the water of the canal, musical underscoring to enhance the atmosphere of individual sequences, and the inclusion of 'proscenium servants'. This final device highlighted the director's training under champion of the avant-garde Vsevolod Meierkhold, as Gail Lenhoff observes:

In [Aristocrats], the use of stage servants in blue dungarees who created the conventional illusions (throwing white flakes to simulate a blizzard, running with branches past a woman on skis to simulate a swift movement down a slope) was clearly derivative. His baring of the theatrical device amounted to a series of ingenious variations on techniques of Chinese and Japanese theatre employed by Meyerhold some fifteen years earlier (Lenhoff, 1973, 95 - 96).

Although Okhlopkov's work was derivative of Meierkhold's practice in his use of proscenium servants, the adaptation of a technique clearly associated with Meierkholdian theatre indicates an affiliation with the aesthetics of the avant-garde. In the comparison of Zakhava's and Okhlopkov's approaches, it seems that Pogodin's play lent itself to both a psychologically realist and a more avant-garde staging. ${ }^{5}$

\footnotetext{
${ }^{5}$ It is interesting to note that according to Marc Slonim, both Zakhava and Okhlopkov withdrew from their more experimental work under the threat of Stalin's purges towards the end of the 1930s: 'In the rea of trials and terror, political recantation was followed by "artistic penance." Okhlopkov, Zakhava,
} 


\section{Avant-Garde temporal aesthetics: the simultaneous perpetual present}

Okhlopkov's production choices brought out an element of avant-garde hybridity that is embedded in Pogodin's text, despite its seemingly straightforward socialist realist intentions. The influence of the avant-garde on Pogodin's writing can be seen particularly in the temporal aesthetic employed in Aristocrats. More than the chronology of the play's narrative (which, in Aristocrats is straightforward and linear), the temporal aesthetic is an approach to temporality embedded within the play text or theatrical performance. The notion of temporal aesthetics is closely associated with visual art, and particularly with the art of the avant-garde, for whom the rejection of linear temporality was a foundational aspect of their practice. The artists of the early twentieth century avant-garde were actively involved in discussion around emerging models of temporality intended to disrupt accepted positivist norms in philosophy, mathematics and physics.

These developments facilitated a new understanding of how time could be incorporated into a canvas, outside of any narrative structure, and the conscious association of the artwork with an anti-linear temporal model became a fundamental marker of avant-garde style. The cubist artists, for example, were fascinated by Henri Bergson's durational temporality, which contributed to their development of mobile space, representing an object simultaneously from multiple angles and equating the experience of viewing the canvas with an extended experience of the object in four-dimensional spacetime (see, for example, Antliff and Leighton, 2001). Similarly, artist Kasimir Malevich engaged with a new temporal structure through the work of P. D. Ouspensky, who proposed a spatialized reading of time that turned temporal progress

and many others publically recognized their former mistakes and repudiated "estheticism, individualism, formalism, and other bourgeois deviations"' (Slonim 1961, 326). 
into a surface, closely related to the principles found in Edwin Abbott's Flatland (1884), a novel investigating perception as it would be from an entirely two- dimensional perspective. Ouspensky extends this reasoning to consider the possibility of temporal experiences being the interaction of the three-dimensional world with a larger fourdimensional universe that cannot be perceived. The result is a reconceptualization of time as a surface, and the subsequent creation of the 'hypercube' form: a fourdimensional shape represented in two dimensions. For the artists of the avant-garde, the use of the hypercube introduced the fourth dimension to the canvas, allowing for a new form of temporal engagement: a new temporal aesthetic, which can be seen, for example, in Malevich's designs for the futurist opera Victory over the Sun [Pobeda nad solntsem] (1913) (see Henderson 1983). ${ }^{6}$

The avant-garde fascination with anti-linearity is also expressed in a distrust of chronological temporal progression and an interest in the notion of simultaneity. Simultaneity is the temporal aesthetic of all-at-once, the construction of a temporality that does not necessarily progress, but instead simply exists. For the artists of the avant-garde, temporal simultaneity was a form of spatialized time, in line with the ideas of Ouspensky or Einstein. Harry Polkinhorn makes the spatio-temporal implications of simultaneity evident in his analogy of space travel:

If the purpose of a spacecraft is to travel through space, the faster we move the shorter the amount of time elapsed. Pushing the model to its extreme, we see that instantaneous transport, the hypothetical ideal state of the system, in which speed is totalized, eliminates time as a category separable from any other, which logically eliminates space, its complement. Thus one can speak either of spatial or of temporal simultaneity (Polkinhorn 1989, 221).

\footnotetext{
${ }^{6}$ See Skinner 2015 for more on the relationship between spatial models of dimensionality and their influence on Russian scenography.
} 
The result is a form of 'simultaneous perpetual present', in which the separation of temporality into past, present and future no longer exists, and time simply is. In visual art, this model can be seen particularly, as Polkinhorn argues, in collage, where the artist uses incomplete pieces of other images to create a canvas in which different temporal and spatial fragments exist together. In this instance, linear temporality, manifest as narrative in realist painting, is replaced by an artwork that allows the viewer to engage with all its moments at once, in the here-andnow of the perpetual present. In Picasso's collage Still Life with Chair Caning (1911-12), for example, the collage fragments forefront the surface of the canvas without directing the viewer's attention to any specific area. The viewer must then choose how to engage with the image, mentally sorting through the fragments which are presented all at once and with equal spatial weighting. Avant-garde engagements with simultaneity can also be seen in a theatrical context in the work of Gertrude Stein, who consciously collapses fine art and theatre by writing a theatrical text that would prompt a form of perceptual engagement that echoed the tenets of canvas painting. Of her opera Three Saints in Four Acts, she comments: 'All these things [the lives of the saints] might have been a story but as a landscape they were just there and a play is just there' (Stein 1935, 1957, 131).

\section{Perpetual present in a socialist realist context}

When considered from the perspective of simultaneity, the temporal aesthetic on which Aristocrats is founded has much in common with that of the Russian avant-garde. The key to exploring this simultaneity is found in how Pogodin handles the play's source material. It is significant that, by the time Aristocrats received its first performances, the work on the Belomor Canal had been completed, and the play therefore deals with Soviet history: events 
that are in the (albeit recent) past. Pogodin treats the events at Belomor with a light touch, and the actuality of inmate experience does not inflect the overwhelmingly positive tone of the play. In reality, the work at Belomor was dangerous and the loss of life high: in her history of the Russian Gulags, Anne Applebaum estimates 25,000 inmate deaths (Applebaum 2012, 79). Bearing in mind the Writers' Brigade context of Pogodin's experience of Belomor, the manipulation of events at the forced labour camps in Aristocrats is hardly surprising, and Ruder notes that the play 'illustrates how Pogodin manipulated dramatic discourse, steeped in theatricality, and dependent on performance, to create and visually sustain the notion of reforging [perekovka]' (Ruder 1998, 156). This is particularly seen in the structure of the play, which was key to its success, as Slonim observes:

What redeemed Pogodin's play from becoming an illustration of a thesis were his humour and his technique: Aristocrats, like Pogodin's other works, replaced the 'trunklink action' of a single plot by a sequence of short episodes or dramatic scenes, each having its own climax and resolution, very much like cinematic shorts. Excellent dialogue and unity of the main theme tied all these separate skits into a scenic whole (Slonim 1961, 311).

Pogodin uses the episodic structure to introduce a range of characters, each of which responds individually to the experience of reforging. The use of focal characters (Kostya, Sonya and Sadovsky) gives the text unity and through-line, whilst still making the most of the range of identities and backgrounds found at Belomor. The enactment of each character's moment of revelation and individual experience of reforging during the performance layers up multiple reforging experiences for the spectator, adding weight to the argument through the sheer volume of conversions seen on stage. Significantly, however, and unlike the reality of Belomor, each inmate survives their reforging experience. 
Pogodin's Aristocrats, however, is not just an example of an individual writer manipulating an individual historical event for the purposes of perekovka. Instead, it is an example of the application of a form of temporal simultaneity to Soviet playwriting. For those in the West, it is perhaps the word 'realist' that is the most problematic aspect of the socialist realist plays. Writing about socialist realist portrayals of Lenin, Maurice Friedberg refers to the work of Abram Tertz:

In his essay On Socialist Realism, Tertz wrote of the incompatibility of an ostensibly realistic style in writing with religious or mythological contents [...] The ostensible realism of Soviet prose, drama and verse [...] often results in portrayals of Lenin that strike infidels and non-believers as ludicrous $(1977,127)$.

Tertz and Frieberg's objections are based on the 'believability' of socialist realist writing, that in the context of perekovka, the style of the writing itself makes it difficult to accept the representations as 'realistic', or even 'realist', from an outside perspective. The socialist realist portrayals are so sincere, in fact, that they do not actually seem true. Socialist realism is associated with words which, in Western theatre, are viewed as distinctly anti-realist mythology, idolatry, and, in Spencer E. Roberts' analysis, the notion of the 'Mystic' as articulated by John Marcus. These words imply a specific relationship with historical events; an interactivity. In Roberts' words, 'From the first sorties into history, it became obvious that corrective measures were necessary if the past were to serve the present effectively' (Roberts $1965,5)$.

What this implies is a de-historicization of history - a moving of historical events into the present, reframing the past as part of today, in a model that is akin to the avant-garde's simultaneous perpetual present. Pogodin's choice to end his play with the canal's completion is a significant one: this replaying of the completion moment - a moment that encompasses 
both the completion of the canal as a physical monument and the completion of perekovka as individual revelation - becomes a repetition of the victory of the Soviet project realised in front of the spectator on a nightly basis. The past, quite literally, becomes the present moment. That this re-enacting deviates from the historical actuality of the events at Belomor indicates a very specific attitude towards the historical operating in the socialist realist aesthetic. Unlike Brecht's model of historicization (see, for example, Brecht 1974), Pogodin's re-writing of Belomor relies not on distance, but on simultaneity. His re-writing of the past is to support and legitimize the present. For the Soviet view of history, the effect of this temporal aesthetic is arguably similar to the, intensely theatrical, perpetual presence of Lenin, also by 1934 a historical figure, who remained part of day-to-day life, overlooking town squares in statue form, or even laid in state, perpetually present in a most literal sense.

It is, in fact, possible to read simultaneity as embedded in the Soviet project, particularly through the spatialization of temporal progress, seen in the mass industrialization of the Five Year Plans. ${ }^{7}$ There is a sense of immediacy in projects such as Belomor, Magnitogorsk and perekovka, which bring the future into the present, suggesting that the success of the Soviet project already exists, extant but elsewhere. The model, in other words, is spatial and simultaneous: somewhere else, right now, change is happening. Canals are being built; people are being reforged. This spatialization of progress highlights the significance of the continual reduction of the timescales for the Five Year Plans themselves: drawing on Polkinhorn's model of the simultaneous, the faster the events occur, the more speed is totalized and time is

\footnotetext{
${ }^{7}$ This reading of spatial and temporal models of progress is indebted to Susan Buck-Morss' work on utopias in Dreamworld and Catastrophe: The Passing of Mass Utopia in East and West (2000). However, in contrast to Buck-Morss' model, I consider communist utopia to have more in common with spatial models of progress, and early twentieth century capitalist utopia (with its emphasis on pleasure deferred to an indiscriminate point in the future) to be more in line with a temporal model.
} 
eliminated, manifesting progress in the everyday. In other words, the nearer to an instantaneous perpetual present, the better.

\section{A visual analogy: Aristocrats and the vortex}

Returning to Okhlopkov's production of Aristocrats, simultaneity and the collapse of past and present find a striking visual and scenographic analogy in the form of the vortex. Okhlopkov's aesthetic experimentation at the Realistic Theatre was founded on the venue's particularly small auditorium, seating only 325 spectators (see Harbeck, 1996). On his acquisition of the theatre, Okhlopkov removed the fixed seating blocks, and introduced a flexibility in the seating arrangements that allowed him to reconfigure the space for each production. The configuration for Aristocrats comprised two raised platforms placed amongst the seating, as Worrall describes:

Two large oblong platforms, rounded at one end and each measuring 5 metres by 3.5 metres, were placed corner to corner in the centre of the auditorium and raised about a metre from the ground, providing a playing length, wall to wall, of 14.6 metres. Both platforms were covered with canvas and the audience were placed around three sides of it (Worrall 1989, 162).

Particularly noteworthy in this staging configuration is the orientation of the chairs against the orientation of the platforms. When viewed from above, it is clear that these two elements, which make up the space's primary visual idiom, are placed in contrasting orientations: the lines of the platforms create a cross on a simple $x-y$ axis through the space; against this, the seating is aligned in diagonal rows. Because of the contrast between the lines of chairs and the platform stages, the choice of orientation for the seating feels somewhat counter-intuitive, the result is a visual tension between these two elements in the space. ${ }^{8}$ What this contrast does create,

\footnotetext{
${ }^{8}$ A diagram of the set viewed from above can be found in Lenhoff (1973).
} 
however, is a centre point for the performance around which the staging and seating appears to be orientated, and the two different dynamics appear to operate. The contrast of an x-y axis with diagonal lines gives the space a sense of rotation around this centre point, creating a spatial analogy for the form of the vortex, a popular reference point in early twentieth century avantgarde art, particularly in English Vorticism but also in some futurist experiments (for example, in the structure of Carlo Carrà's 1914 collage, Patriotic Festival). The identification of the vortex in Okhlopkov's configuration is significant in that the form has a particular temporal

implication associated with the collapse of past and present. Henry Michael Gott notes that the vortex 'was persistently invoked [...] to capture a sense of temporality either cultural or personal' and was '[granted] an autonomy in the transmission between past and future' (Gott 2013, 145). The vortex form in Okhlopkov's production becomes a metaphor for simultaneity, echoing the temporality of the text and embedding a profoundly avant-garde scenographic and dramaturgical metaphor within the socialist realist production.

\section{The avant-garde hybrid at the Hinterlands}

The analysis of Aristocrats as an example of early socialist realist writing and performance draws attention to the hinterlands of the avant-garde. The examination of these boundary moments, when avant-garde practice begins to be rejected, is vital in developing a wider understanding of how the historical avant-garde functioned and how its legacy might be defined. The identification of the simultaneous perpetual present in Aristocrats suggests that this play is a form of transitional hybrid between the avant-garde and the post-avant-garde in early twentieth century Russia, where avant-garde technique is seen in the service of a fundamentally non-avant-garde theatrical form. The hybrid models allows for the consideration of how texts in the avant-garde hinterlands use elements of avant-garde aesthetics to manage the transition 
out of the avant-garde moment. The value of this hybrid, above all, is in establishing avantgarde legacy outside of an avant-garde context. The hybridised work suggests models for avant-garde legacy that operate outside of terms such as 'experimental' or 'challenging', whose definition is unreliable at best, as well as side-stepping the problems of normalisation to which formerly avant-garde techniques can be subjected. Aristocrats, when read as a hybrid, demonstrates how avant-garde thinking is embedded in post-avant-garde practice. Counterintuitive though it may seem, and despite the deplorable consequences of the socialist realist project for the artists of the avant-garde, Pogodin's play and similar hybridised texts are models of on-going avant-garde vitality and life when the political context no longer supports overt formal experimentation. Without serious consideration of these texts, and the hinterlands they represent, the history of Russia's avant-garde will always be a partial one.

\section{Bibliography of works cited}

Abbott, Edwin. 1884. Flatland: A Romance of Many Dimensions. London: Seeley.

Antliff, Mark and Patricia Leighten. 2001. Cubism and Culture. London: Thames and Hudson.

Applebaum, Anne. 2012. Gulag: A History. London: Penguin Books.

Brecht, Bertolt. 1974. 'A short description of a new technique of acting which produces an alienation effect' trans. John Willet in Brecht on Theatre, edited by John Willet, 136 - 147. London: Eyre Methuen.

Buck-Morss, Susan. 2000. Dreamworld and Catastrophe. Cambridge, Mass.: MIT Press.

Drascokzy, Julie. 2012. 'The Put' of Perekovka: Transforming Lives at Stalin's White Sea-Baltic Canal.' The Russian Review 71: 30 - 48.

Friedberg, Maurice. 1977. 'Solzhenitsyn's and other Literary Lenins.' Canadian Slavonic Papers/Revue Canadienne des Slavistes 19 (2): 123 - 137.

Gott, Henry Michael. 2013. Ascetic Modernism in the Work of T. S. Eliot and Gustave Flaubert. London \& New York: Routledge.

Groys, Boris. 2011. The Total Art of Stalinism: Avant-Garde, Aesthetic Dictatorship, and Beyond, translated by Charles Rougle. London \& New York: Verso. 
Harbeck, James. 1996. 'Okhlopkov and the Nascence of the Postmodern.' Theatre Insight 7 (1). Available at http://www.harbeck.ca/James/JH_Okhl.pdf [accessed 12/07/2016].

Henderson, Linda Dalrymple. 1983. The Fourth Dimension and Non-Euclidean Geometry in Modern Art. Princeton, N.J.: Princeton University Press.

Houghton, Norris. 1938. Moscow Rehearsals. London: George Allen and Unwin Ltd.

Lenhoff, Gail. 1973. 'Spectator and Spectacle: The Theatre of Okhlopkov.' The Drama Review 17 (1) ('The Russian Issue'): 90 - 105.

Pogodin, Nikolai. 1937. Aristocrats, translated by Anthony Wixley, in Four Soviet Plays, edited by Ben Blake, 178 - 304. London: Lawrence and Wishart.

Polkinhorn, Harry. 1989. 'Space Craft: Collage Discourse' Collage: Critical Views, edited by Katherine Hoffman, 213 - 224. Ann Arbor: UMI Research Press.

Roberts, Spencer E. 1965. Soviet Historical Drama: Its Role in the Development of a National Mythology. The Hague: Martinus Nijhoff.

Rudenstine, Angelica Zander. 1981. 'The George Costakis Collection' in Art of the Avant-Garde in Russia: Selections from the George Costakis Collection, edited by Angelica Zander Rudenstine and Margit Rowell, 9 - 14. New York: Solomon R. Guggenheim Foundation.

Ruder, Cynthia Ann. 1998. Making History for Stalin: the Story of the Belomor Canal. Gainsville: University Press of Florida.

Schechner, Richard. 1996, 2002. 'The Five Avant Gardes or... or None?' in The Twentieth Century Performance Reader, edited by Michael Huxley and Noel Witts, 342 - 358. London \& New York: Routledge.

Skinner, Amy. 2015. 'Surfaces, Depths and Hypercubes: Meyerholdian Scenography and the Fourth Dimension.' Theatre and Performance Design 1 (3): 204 - 219.

Slonim, Marc. 1961. Russian theatre from the Empire to the Soviets. London: Methuen.

Smeliansky, Anatoly. 1999. The Russian Theatre after Stalin, translated by Patrick Miles. Cambridge: Cambridge University Press.

Solovyova, Inna. 1999. 'The Theatre and Socialist Realism, 1929 - 1953' in A History of Russian Theatre, edited by Robert Leach and Victor Borovsky, 325 - 357. Cambridge: Cambridge University Press.

Stein, Gertrude. 1935, 1957. Lectures in America. Boston: Beacon Press.

Stetsky, A. I. 1977. 'Under the Flag of the Soviets, Under the Flag of Socialism' in Soviet Writers Congress, 1934, edited by H. G. Scott, 261 - 274. London: Lawrence and Wishart Ltd.

Van Gyseghem, André. 1943. Theatre in Soviet Russia. London: Faber and Faber Ltd.

Westerman, Frank. 2011. Engineers of the Soul: In the Footsteps of Stalin's Writers. London: Vintage. 
Worrall, Nick. 1989. Modernism to Realism on the Soviet Stage: Tairov, Vakhtangov, Okhlopkov. Cambridge: Cambridge University Press.

Zhdanov, Andrei. 1977. 'Soviet Literature - the Richest in Ideas, the Most Advanced Literature' in Soviet Writers Congress, 1934, edited by H. G. Scott, 15 - 26. London: Lawrence and Wishart Ltd. 